\title{
The Decline of Indonesia's Leadership Role in ASEAN: Systemic and Domestic Constraints of Jokowi's Foreign Policy Alterations
}

\section{Darwis}

\author{
Bama Andika Putra \\ Department of International Relations, \\ Universitas Hasanuddin, \\ Jl. Perintis Kemerdekaan No.KM.10, \\ Tamalanrea Indah, Kec. Tamalanrea, \\ Kota Makassar, Sulawesi Selatan 90245, \\ Indonesia
}

DOI: https://doi.org/10.36941/ajis-2022-0o10

\section{Abstract}

This article addresses how systemic stimuli and domestic constraints, specifically on the perception of foreign policy executives, influence Indonesia's leadership decline in ASEAN under Joko Widodo's first presidential term. Through the lens of neoclassical realism, it is concluded that Indonesia's leadership decline in ASEAN is attributed to the changing geopolitical landscape of Asia, with the assertive rise of China and the need to find other models of grand strategies in facing the regional hegemon. Furthermore, there is a unified perception of the irrelevance of maintaining a leadership role in ASEAN, and how the foreign policy executives of the Indonesian President and the Indonesian Ministry of Foreign Affairs have concluded to this approach. Implementation of this research is the contribution to the foreign policy framework in facing certain systemic stimuli in the region of Asia, and to understand the role of a unified perspective among foreign policy executives to the actual output of foreign policy. This article contributes to the discourses of; (1) neoclassical realism, specifically on the role of systemic stimuli and elite perceptions as intervening variables in understanding alterations in foreign policy behavior, and (2) empirical analysis of Indonesia's leadership role in ASEAN during the presidency of Joko Widodo.

Keywords: Regionalism, ASEAN, Neoclassical Realism, Jokowi

\section{Introduction}

The Association of Southeast Asian Nations (ASEAN) has always become Indonesia's cornerstone of foreign policy. As one of the founders of ASEAN, the regional organization has evolved, becoming a major priority for Indonesian presidents throughout the years (Tan, 2015). Furthermore, Indonesia has shown to, in many cases, embracing a leadership role in ASEAN through the introduction of imperative norms and institutions to guide ASEAN in the geopolitical shifts of the $2 \mathbf{1}^{\text {st }}$ century (Darwis, Putra, \& Cangara, 2020). However, since the inauguration of Joko Widodo (Jokowi) in 2014, several scholars have noted that this leadership role has declined (Acharya, 2018; Storey, 2018), due to shifts in the national interest and governmental prioritizations. In Jokowi's first presidential term, he 
is well known for the inception of the 'Global Maritime Axis' (GMA), which positions a strong emphasis on maritime-based developments. Recently, Jokowi has also stated in rhetoric and implemented in practice, his priority of inward developments, economic diplomacy, and foreign policies to attract investments (Aji \& Dartanto, 2018; Negara \& Suryadinata, 2019; Poole, 2015). Though Jokowi continuous his activeness in the organization, the level of Jokowi's leadership in ASEAN is significantly distanced compared to his predecessors. The actual decline of Jokowi's leadership role in ASEAN is alarming, considering that Indonesia is a country that has based its past foreign policies to engage in the closest regions of Southeast Asia. As one of the most thriving democracies in the region, Southeast Asian states have benchmarked best democratic practices to Indonesia, in an attempt to 'democratize' the region at faster rates.

In an attempt to understand this phenomenon, this article will focus on possible explanations to this reality, which includes how systemic stimuli influences foreign policy behavior, and how the perceptions of foreign policy executives (specifically of the president and Indonesian Ministry of Foreign Affairs (MOFA)) results to certain directions of foreign policy.

A major phenomenon that provides context to this article is the recent tensions in the South China Sea that include Indonesia's sovereignty over the Natuna Waters. The Indonesian public was recently shocked by the trespassing of Chinese fisher boats and coastguards into the Exclusive Economic Zone of Indonesia. Jokowi showed that in rhetoric, he is not moved by any attempts of infiltration and illegal trespasses. However, in reality, he is not able to provide a proper response to crises alike, considering the vast infrastructural investments that Indonesia has attained from China in recent years. As the level of assertiveness of China grows, Indonesian policymakers have deliberated whether past actions of prioritizing Indonesia's leadership role in ASEAN should be maintained. In Jokowi's first presidency, it was clearly evident that he was willing to take a different route of foreign policy. Therefore, this article will attempt to fill in two research gaps, which include; (1) deductively implementing neoclassical realism in an attempt to understand state-International organization interactions and foreign policy outcomes, and (2) empirical analysis of Jokowi's decline of the leadership role in ASEAN.

\section{Literature Review}

This section will elaborate on the two fields of international relations discourse that the article will directly contribute to, including; (1) expanding the discourse of neoclassical realism's relevance in explaining state-organizational interaction, (2) empirical contributions to the analysis of Indonesia's contemporary leadership role in ASEAN.

The first section of this literature review focuses on the discourse of neoclassical realism in foreign policy analysis. This research follows up a past article published in 2015 under the title "Indonesia's Leadership Role in ASEAN: History and Future Prospects" (Putra, 2015). In justifying Indonesia's past and contemporary leadership role in ASEAN, Putra argues that the theory of neoliberal institutionalism provides firm explanatory capacities in analysing how states compromise in achieving collective goals through international institutions (Putra, 2015). In addition to that, the article also employs the hegemonic stability theory, in which Indonesia as a hegemon of the regional organization will push agendas to favor its position, but will coincide with its leading role to provide public goods (Emmers, 2014). Since then, the political environment of Indonesia's foreign policy has shifted and even resulted in changes to Indonesia's foreign policy grand strategies. This article argues that currently, Indonesia is in a state of decline in its past leadership role in ASEAN. The decline is defined as a gradual decrease in leadership-based roles in ASEAN, not the complete depletion of the role. In testing the hypothesis, implementing neoliberal institutionalism and hegemonic stability theory will not provide enough clarity to explain the recent foreign policy anomaly. This research thus employs neoclassical realism in understanding the current shifts in foreign policies that have led to Indonesia's leadership decline in ASEAN, considering the equal importance of systemic and domestic constraints. 
In comparison to its predecessors in the realism school, neoclassical realism evaluates the state's relative power in the international system (independent variable), domestic constraints (intervening variable), and foreign policy outcomes (dependant variable). Similar to past assumptions on foreign policy analysis, neoclassical realism considers the equal role that the system and domestic environment factors lead to certain foreign policies of a state. Past literature has been much in favor of the assumption that both systemic and domestic factors equally lead to a comprehensive explanation of foreign policy behaviors (Rose, 1998). In comparison to past perspectives in the Realism paradigm, neoclassical realism has gained popularity as it does not neglect domestic level variables (Beach, 2019; Putra, 2020). Several scholars focus on the aspect of the processes that distort decision making (Rathbun, 2008), the equal impacts of the unit and systemic analysis (Zakaria, 1991), and how it would be difficult to disconnect between the unit and systemic variables (Schweller, 2004; Zakaria, 1998).

Neoclassic realism differs itself with the inclusion of domestic constraints as its intervening variable. Although it provides a unique insight into understanding foreign policy besides a pure structuralist engagement, the domestic constraints chosen are still debatable. Many scholars have criticized how the unit level analysis is underdeveloped, and unclearly justified why some domestic variables are chosen and some are neglected (Kaarbo, 2015; Kozub-Karkut, 2019). This research refers back to the book Neoclassical realist theory of international politics (Ripsman, Taliaferro, \& Lobell, 2016) and analyzes how domestic constraints that specifically include (1) elite perception, (2) strategic culture, (3) state-society relations, and (4) domestic institutions, impact foreign policy behaviors as intervening variables. But in its implementation, the research will focus on elite perception alone, with hopes of testing how far can the constraint of elite perception on a foreign policy matter, along with systemic factors, influence foreign policy behaviors. This is where the research gap is positioned. Past literature of employing neoclassical realism has been focused on issues of security concerns (Syailendra, 2017), the balance of interest (Schweller, 2004), the balance of risk (Taliaferro, 2004), and grand strategy formulations (Kitchen, 2010). There has not been any literature that attempts to explain changes in foreign policy behavior of state actors towards international organizations. Therefore, this research contributes significantly to the discourse of neoclassical realism, by focusing on a research gap that attempts to analyze how a state's relative power in the International System and a single intervening variable of elite perception can explain alterations in foreign policy behavior. It directly contributes to the discourse as past literature positions all intervening variables as equally contributive towards the outcome of foreign policy behavior, and none have attempted to focus on state-International organization interactions.

The second section of this literature review focuses on the contemporary trends of Indonesia's leadership role in ASEAN. As stated in the first section, this article follows up the analysis of the past article written in 2015, which focuses on mapping forms of Indonesia's leadership in ASEAN. The past presidency of SBY has led the implementation of a number of foreign policy grand strategies, including dynamic equilibrium, a thousand friends zero enemies, and geographic proximity (Inayati, 2016). The outcome of Susilo Bambang Yudhoyono's (SBY) foreign policy is a focus towards regional cooperation through ASEAN, which eventually expands Indonesia's influence through the inclusion of major powers to the regional framework set in Southeast Asia. Many academics have highlighted Indonesia's leadership role in establishing institutions and norms to ASEAN during SBY's presidency (Anugrah, Putra, \& Burhanuddin, 2020; Caballero-Anthony, 2005; Darwis, Putra, Benny, Baharuddin, \& Burhanuddin, 2020; Emmers, 2014; B A Putra, 2020). Indonesia knew its comparative advantage against Southeast Asian states, and led the discourse and formation of the ASEAN Political-Security Community, and also in the field of human rights through the ASEAN Intergovernmental Commission of Human Rights (Pisanò, 2014). Putting aside the effectiveness of the established programs and institutions, the formation itself is a key representation of Indonesia's leadership in forming new norms and institutions for ASEAN. This is not without its risks, as the introduction of human rights to ASEAN members is known as a sensitive issue for states that have only implemented partial aspects of human rights regimes into domestic policies. Widiyanta (2016) in his article 
highlighted this success, on how Indonesia's leadership role can be reflected by its role in the democratization of Southeast Asia in the $21^{\text {st }}$ century. In regards to Indonesia's leadership, some studies also indicated how Indonesia's soft power had been a key determinant of ASEAN's success in the past (Rattanasevee, 2014).

The literature on Indonesia's leadership role in ASEAN in Joko Widodo's (Jokowi) first presidency term is scarce. A simple explanation as to the lack of study on this topic correlates directly to Jokowi's defined grand strategy of GMA, which positions Indonesia in a strategic position connecting between The Indian and Pacific Oceans. Unlike SBY's geographic proximity that positions Southeast Asia as the main priority of foreign policy, Jokowi does not specify regions of interest, but to key issues of maritime-based policies that will be prioritized for his first presidential term. Another result of this is the development of a foreign policy discourse that is inward-oriented, rather than outward.

Based on geographic significance, Indonesia's foreign policy discourse has developed towards Indonesia's view and position in the strategic region of the Indo-Pacific. Bagus, Agastia, \& Perwita (2015) elaborated on Indonesia's contemporary role in the Indo-Pacific, and Putra (2017) went further to focus on Indonesia's urgency to focus its foreign policy towards the Indian Ocean Rim Association. Furthermore, Jokowi's GMA resulted in a new Indonesian foreign policy discourse that focuses on Indonesia's sea-oriented foreign policy (Connelly, 2015). Existing studies also focused on Jokowi's prioritization towards pro-people diplomacy, and advancing economic opportunities for the Indonesian people (Darwis, Putra, Benny, et al., 2020). Studies from Andika (2016), Haryono (2019), and Warburton (2016) equally contribute to the discourse of economic diplomacy, and how Jokowi has framed his foreign policy to find new economic opportunities. A question that surfaces thus is how ASEAN is positioned in Jokowi's strategic foreign policy outlook? Does it still consider it as strategic in the provision of Indonesia's foreign policy goals? Moreover, it begs the question of whether Indonesia still considers its leadership role in ASEAN or a mere international organization of which Indonesia is a member of. This is where this article will contribute to, which is the research gap of the possibility of Jokowi's leadership role decline in ASEAN, which will go against past studies stating that Indonesia is a 'natural born leader of ASEAN' (Roberts \& Widyaningsih, 2015).

\section{Methodology}

This research is a qualitative research that comprises of both primary and secondary data related to Joko Widodo's leadership role in ASEAN. The primary data is taken from several governmental archives and documents, meanwhile, secondary data is extracted from relevant books, journal articles, and electronic resources. The time limit for this study is 2014-2019 (first presidential term of Joko Widodo), as there have been major shifts of grand strategies declared under the presidency, and which have been consistently against past traditional engagements towards ASEAN. Throughout the analysis, the authors will attempt a deductive approach that develops the central question based on the specific theory that is deemed most relevant in analyzing the issue of contemporary IndonesiaASEAN relations.

In analyzing the trends leading to the possible conclusion of this research, the authors employ Neoclassical Realism to understand the possible decline of Indonesia's leadership role, by evaluating factors of systemic stimuli and domestic constraints leading to the decline of the leadership role. By the end of this article, the question that will be addressed is 'How significant are systemic stimuli and domestic constraints towards Indonesia's Decline of ASEAN?' In answering the research question, the independent variable is 'Indonesia's relative power in the international system' (systemic factors), intervening variable to include 'elite perceptions,' and the dependent variable to elaborate on the foreign policy behavior of Indonesia towards ASEAN in Jokowi's first presidential term.

It is worth addressing that analysis of neoclassical realism concludes four different intervening variables. They include (1) elite perception, (2) strategic culture, (3) state-society relations, and (4) domestic institutions (Ripsman et al., 2016), which all act as constraints towards the central actors in 
the process of foreign policy decision-making. In justifying the exclusions made, the authors argue its relevance towards Neoclassical Realism because; (1) reference towards systemic stimuli as the cornerstone of Indonesia's external behavior in international affairs, and (2) significance of elite perception in contemporary neoclassical realism studies (Schweller, 2004).

There have been ongoing debates among neoclassical realist scholars as to which intervening variable holds greater significance to explain domestic constraints compared to other variables, and in several instances, it has become the major criticism. Stephen Walt (Ripsman et al., 2016), for example critiques how neoclassical realism employs intervening variables in an ad hoc manner, with others stating the list of variables are too wides (Legro \& Moravcsik, 1999). Part of the methodology of this article is the specification of a single intervening variable to represent the domestic constraints in foreign policy behavior, in order to avoid incomplete analysis and vague arguments. In addition, this research also specifies foreign policy executives as the Indonesian President and Indonesian Foreign Affairs Minister, due to their relevance in the formulation of foreign policy outcomes related to state-international organization interactions. The alternative model of foreign policy analysis of this article thus will be framed as below:

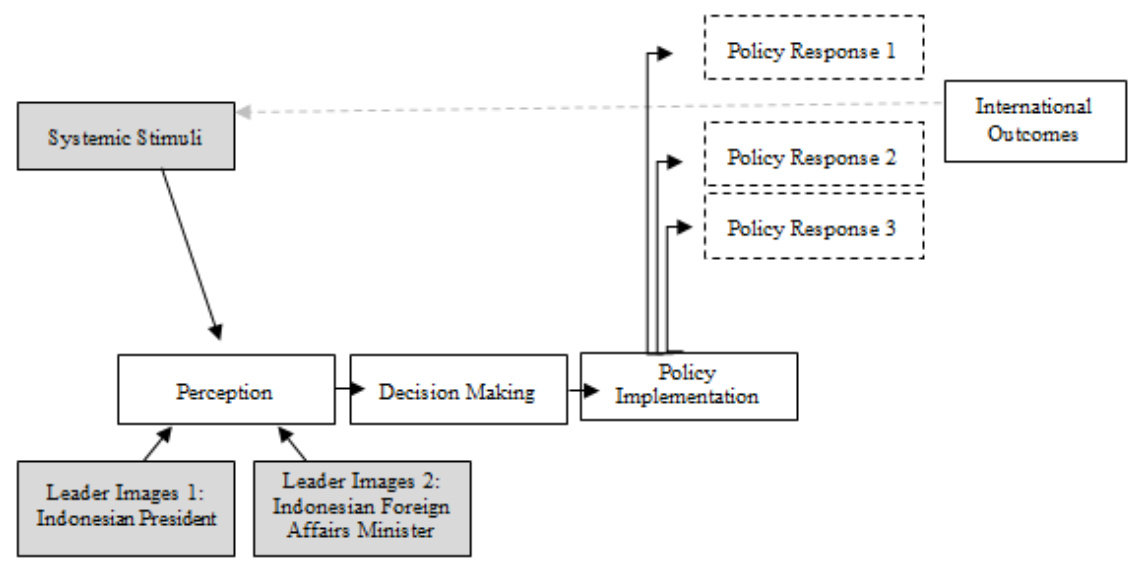

Figure 1: Model of Neoclassical Realism Foreign Policy Analysis for the research (adapted from Ripsman, Taliaferro, Lobell, 2016)

Source: Neoclassical Realist Theory of International Relations (2016)

\section{Results \& Discussion}

This article argues that the stance of Indonesia's leadership decline is due to systemic stimuli and the perceptions of Indonesian foreign policy executives. Joko Widodo's grand strategy in the 21st-century Indonesian foreign policy is the implementation of the Indonesian GMA, positioning Indonesia as the hub of the Indian and Pacific Oceans (Anwar, 2020). The doctrine consists of 5 major pillars, including maritime culture, maritime development, maritime economy, maritime diplomacy, and maritime security (Bagus et al., 2015). Since the electoral debates in 2014, until the end of Jokowi's first presidential term, this notion of maritime-based development, pro-people diplomacy, and economic diplomacy, have been the major rhetoric of Jokowi in advancing national interest (Syailendra, 2017). There is no doubt that the foreign policy rhetoric has shifted from exerting influence regionally, to a more inward-based foreign policy for the people (Kuncoro et al., 2020; Syailendra, 2017).

Since 2014, the only notable role of Indonesia has been the formation of the ASEAN Outlook on the Indo-Pacific (Anwar, 2020). An effort to frame the political environment of the Indo-Pacific, and 
how Indonesia can engage in the region. The policy does align itself with Jokowi's vision of Indonesia becoming a GMA, but this success goes far from being labelled as a leadership role. Compared to his predecessors, Jokowi has not been too invested in establishing new norms and institutions in ASEAN (Tan, 2015). This article though does not argue that the role has completely diminished. Since 2016, Indonesia has still been active in all regional and intra-regional forums of ASEAN, and continues to have recommendations being passed. But leadership embraces fellow members and must fulfil the job of guiding the organization is facing a crisis that is currently and predicted to occur in the region. Therefore, considering its activeness until 2019 and the introduction of an Indo-Pacific outlook, Indonesia is still a major power in ASEAN, but its leadership role has significantly been declined (not diminished). The following section attempts to elaborate on reasons for the leadership decline through the lens of neoclassical realism.

\section{Systemic Stimuli: Assertive Rise of China and the Securing the Indo-Pacific Oceans}

Jokowi's the implementation of the GMA can be interpreted due to a number of causes. The major issue that needs to be highlighted is the regional political-security environment of Asia beginning in the early $21^{\text {st }}$ century. China has rapidly advanced its artificial islands in the 3 archipelagos of Paracels, Spratlys, and Scarborough Schoal (Simon, 2012). Tensions have never ceased between China and Southeast Asian claimant states, with strong criticisms directed to China's 11 dash line map (Putra, 2021). The claims thus have resulted to ASEAN member states such as the Philippines, Vietnam, Brunei, Malaysia, and Indonesia, to take a tough stance against China in cases related to the South China Sea. Major issues include China's placement of an oil-drilling rig inside the EEZ of Vietnam in 2014, and also China's disregard towards the South China Sea Arbitration that was decided in 2016 (Heydarian, 2017). China is not emerging as a global superpower, in an international system that is categorized as multipolarity. For classical realists, this is a system that causes chaos and conflict, as there is no single power that is able to provide the balance to deter assertive behaviors. Despite the US freedom of navigation in the region, China continues to be assertive in its actions in the region.

ASEAN's role is difficult in instilling cooperative values and confidence-building measures. The initial plan was to implement a Code of Conduct (COC) in the South China Sea, binding China and ASEAN members states as to actions that are permitted and those that are not (Pham, 2010). Despite being under negotiation for more than a decade, ASEAN and China until this date is unable to conclude a COC in the South China Sea. Alternatively, they took an easier route of implementing a Declaration of the Conduct of Parties in the South China Sea, which declares the need to reaffirm friendly relations in the region, but is not legally binding to parties of the declaration (York, 2015). This issue is a major concern of Indonesia, as under SBY, Indonesia attempted to press China's security assertiveness through maximizing the ASEAN framework (Inayati, 2016). But it has only resulted less in taming aggressiveness, as ASEAN itself based on the ASEAN charter, is much constrained of the actions that can be taken. Indonesia for once that used to be able to control the political-security environment of Southeast Asia, is faced with a rising regional hegemon in the case of China. Actions of hedging and bandwagon in the past have not resulted in a less assertive China (Syailendra, 2017).

Furthermore, considering Indonesia's relative power against the regional hegemon, it is not surprising that Indonesia under Jokowi took a more gambled stance to directly engage with possible assertiveness. China has continued with its mass influx of foreign direct investments to Indonesia worth of USD 2.3 billion, majorly for infrastructural purposes (Tokan, 2019). China is in the phase of implementing its Belt and Road Initiative that involves infrastructural developments and investments to countries in Asia, Africa, Europe, the Middle East, and the Americas. Indonesia is also part of this strategic plan, due to its geographic uniqueness. Being the hub of the Indian and Pacific Oceans, the position of Indonesia is inevitably critical for China's Sea Lanes of Communication (SLOC) and border security. In the Pacific Oceans, the major concern is in the South China Sea, meanwhile, the Indian Ocean concerns with a more convoluted issue that relates to the future of China's energy 
security.

Putting context towards the importance of the Indian Ocean is thus imperative before understanding Jokowi's implementation of the GMA. Based on the figures, approximately 32.2 million barrels of crude oil and petroleum are transported through chokepoints in the Indian Ocean (Bagus et al., 2015). Sources of oil including countries such as Saudi Arabia, Kuwait, Iran, and Iraq, have utilized the SLOC of the Indian Ocean to export millions of barrels of oil every day. China is the largest importer of oil (Rioux, Galkin, \& $\mathrm{Wu}$, 2019) with a continuously rising demand for it.

As China's assertiveness rises, Indonesia is not able to keep up with geopolitical dynamics. During SBY's presidency, foreign policies that place a high emphasis on ASEAN and regionalism were introduced as Indonesia needed to test the possibility of suppressing China's assertive rise through the ASEAN framework (Inayati, 2016). With the contemporary dynamics in Southeast Asia, it is clear that Indonesia has not embraced a strategy that is able to suppress such a belligerent actor in the region. Indonesia's hope of instilling peaceful values through ASEAN has failed, and that is why Jokowi decided to re-shape Indonesia's foreign policy with a focus on the Indo-Pacific region, a region of China's interest. This is a response that considers Indonesia's relative power in the region and international system, in this case, against China's assertive rise. Because ASEAN has failed in instilling peaceful values and conflict management functions in the South China Sea issue, Indonesia no longer views a leadership role in ASEAN as a strategic foreign policy in facing a regional hegemon. Investment thus is directed to other attempts, which results in the deficiency of Indonesia's leadership role in ASEAN. To complete the argument, an analysis of foreign policy executive's perceptions towards ASEAN's importance for Indonesia is presented below.

\section{Domestic Constraints of Foreign Policy: The Role of Jokowi's and Ministry of Foreign Affairs Perception in Foreign Policy Outcome}

Based on the foreign policy analysis of the neoclassical realism lens, a unified perception of a threat or the importance of a foreign policy issue is key to an effective foreign policy outcome. Possibilities of differing views will lead to foreign policies that are inconsistent in addressing the foreign policy crisis. This article presents an analysis of how foreign policy executives, in here represented by Jokowi (Indonesian President) and Retno Marsudi (Ministry of Foreign Affairs/ MOFA) perceive the role of leadership in ASEAN during the first term of Jokowi's presidency (Warburton, 2016). Leadership towards a regional organization is defined in this article to concern the president and MOFA for the case of Indonesia, as other possible foreign policy executives do not have a role in determining leadership roles in international organizations. Furthermore, as this article is an analysis specifically to focus on foreign policy grand strategies, both of the designated foreign policy executives are efficient in determining Indonesia's leadership role.

\subsection{Perception of Foreign Policy Executives: Jokowi's Perception of Indonesia's Leadership in ASEAN}

Expectations were high since the election of Jokowi on 20 October 2014, as a pro-people figure (Rizka, Lismalinda, Adnan, Moriyanti, \& Faisal, 2020). Since the electoral campaigns in 2014, it was evident that Jokowi was willing to risk embracing a new form of foreign policy, one that refers back to Indonesia's comparative advantage as an archipelagic state. After being elected, he famously quoted in his inaugural address Jalesveva Jayamahe (at sea we will triumph) (Parameswaran, 2014) followed by the announcement of Indonesia's vision of becoming a GMA, taking advantage of Indonesia's strategic position as the hub of the Indo-Pacific Oceans. Maritime-based developments will be prioritized, both in an inward and outward sense. In the early months of Jokowi's presidency, rarely did he refer Indonesia's leadership to ASEAN as a cornerstone of his term's foreign policy. As many starts to question whether Indonesia will still hold emphasis on ASEAN, Rizal Sukma, Jokowi's then foreign policy advisor stated; "We used to say ASEAN is the cornerstone of our foreign policy. Now we change it to a cornerstone of our foreign policy" (Parameswaran, 2014). Statements such as this are 
critical to consider, referring to the fact that Jokowi is an individual that is majorly dependent on inputs from his policy advisers.

Reviewing Jokowi's first-term foreign policy priorities, categorizations consist of the following; (1) pro-people foreign policy by the protection of Indonesian workers abroad, (2) advancing economic diplomacy for the welfare of the Indonesian people, (3) emphasis towards bilateral partnerships rather than multilateralism, and (4) maritime-based development such as the GMA. Observers may slightly perceive that by a general look at Jokowi's implemented foreign policy, ASEAN is not part of his list. This is, however, not entirely true, especially in Jokowi's first year in office. He maintained a leading role in ASEAN forums, and continues to provide guidance and recommendations for ASEAN's policies. Unfortunately, it was clear that the role taken had immensely declined in comparison to past years, as the introduction of new institutions and norms, guidance in crisis (for example, in cases of the South China Sea), and reluctance to manage regional order and conflicts (in comparison to SBY and Marty Natalegawa), were clearly evident in the following years.

Past leadership functions that Indonesia has been accustomed to having declined, leading to the conclusion that Jokowi's perception of Indonesia's leadership role in ASEAN is not a priority. Jokowi highly emphasized maritime-based developments during his presidency, but unfortunately, it was not through ASEAN. Other means were explored, including the maximization of relations with the Indian Ocean Rim Association (IORA). Furthermore, as many questioned how Jowould will translate the GMA becoming a foreign policy, until 2019, we did not attain a glimpse of that realization, besides Jokowi's activeness in the IORA. It is thus fair to conclude that maritime-based developments framed in the GMA, are purely an inward policy, rather than outward (Rijal, 2019). This is proven by the significant maritime-based developments that have taken place in Jokowi's first term presidency.

\subsection{Perception of Foreign Policy Executives: Indonesian MOFA's Perception of Indonesia's Leadership in ASEAN}

In analysing the perspective of the Indonesian MOFA in regards to their perception over Indonesia's leadership role in Indonesia, this section will provide a qualitative analysis of the performance report of the ministry between the years of 2016-2019. Starting from the year 2016, one of the strategic goals of the Indonesian MOFA is to realize Indonesia's leadership and role in influencing international cooperation (Ministry of Foreign Affairs Indonesia, 2016). One of the defined key performance indicators in this strategic goal is an increased leadership role in ASEAN. The ministry measures this by the percentage of recommendations and initiatives accepted in each ASEAN forum in 2016. A complete list of the number of recommendations and initiatives can be found in the following table.

Table 1: Key Performance Indicator of Indonesia's Leadership in ASEAN based on accepted recommendations and initiatives in 2016

\begin{tabular}{|c|c|c|c|c|c|c|}
\hline $\begin{array}{l}\text { Key Performance } \\
\text { Indicator }\end{array}$ & Field & $\begin{array}{r}\text { Initiatives } \\
\text { Delivered } \\
\end{array}$ & $\begin{array}{l}\text { Initiatives } \\
\text { Accepted } \\
\end{array}$ & $\begin{array}{c}\text { Recommendations } \\
\text { Delivered }\end{array}$ & $\begin{array}{c}\text { Recommendations } \\
\text { Accepted }\end{array}$ & Total \\
\hline \multirow{7}{*}{$\begin{array}{l}\text { Percentage of } \\
\text { Indonesian } \\
\text { Recommendations } \\
\text { and Initiatives } \\
\text { Accepted in Each } \\
\text { Meeting }\end{array}$} & Political & 23 & 22 & 191 & 181 & \\
\hline & Economic & 23 & 18 & 49 & 48 & \\
\hline & Socio-Cultural & 10 & 9 & 84 & 77 & \\
\hline & $\begin{array}{l}\text { ASEAN partnership } \\
\text { with ASEAN partners }\end{array}$ & 7 & 6 & 271 & 269 & \\
\hline & Total & 63 & 55 & 595 & 575 & \\
\hline & \multicolumn{5}{|c|}{ Total Recommendations and Initiatives Delivered: } & 658 \\
\hline & \multicolumn{5}{|c|}{ Total Recommendations and Initiatives Accepted: } & 638 \\
\hline
\end{tabular}

Source: Ministry of Foreign Affairs Republic of Indonesia (2016) 
Table 1 provides a quantitative outlook of Indonesia's activeness, and constant echoing of recommendations and initiatives in ASEAN. Observers may be fast in concluding that Indonesia's leadership role thus has not declined, but maintained in 2016. But based on a qualitative analysis, the recommendations and initiatives do not dictate Indonesia's leadership role, but its activeness in ASEAN forums. Furthermore, the strategic goal of leadership role and influence in international cooperation does not only define ASEAN alone. Other international organizations, partnerships (both bilateral and multilateral) are considered. This is critical to understand as the parameter of leadership in international organizations does not stop in the form of activeness in the provision of recommendations and initiatives, but continues to implement radical but necessary changes in norms and institutions. Out of the 638 recommendations and initiatives in 2016, none was able to conclude the much critical Code of Conduct in the South China Sea, which provides questions on to the significance of the accepted recommendations and initiatives (Ministry of Foreign Affairs Indonesia, 2019).

But the figures continue in the 2017, 2018, and 2019 Indonesian MOFA performance reports. But since 2017, the Indonesian MOFA no longer considers that leadership in ASEAN as a key performance indicator of leadership and influence in establishing international cooperation. The ministry decided to take a wider stance by equally measuring the performance in other international organizations. For example, in 2019, the report places high emphasis on the foreign policy conducts in IORA, and United Nations Security Council (UNSC), as in the case of UNSC, Indonesia recently was elected as a nonpermanent member for the period of 2019-2020. In the 2019 report, Indonesia's role in ASEAN was more of a fulfillment of past roles maintained. It is worthy to note that in 2019, Indonesia was able to take a major role in the introduction of the ASEAN Outlook on the Indo-Pacific (Anwar, 2020). This article praises the conception of this outlook, considering the rise of importance of the region and how it will dictate future international affairs in Asia. But this is a form of leadership decline, in comparison to what Jokowi's predecessors have concluded in regard to Indonesia's leadership role in ASEAN.

By the end of the first term of Jokowi, the Indonesian MOFA thus concluded in their report that they have focused on a $4^{+1}$ formula for Indonesian foreign policy, which includes; (1) strengthening economic diplomacy, (2) protection of Indonesian workers abroad, (3) sovereignty of the Archipelagic State of Indonesia, (4) Advance contribution and leadership in the region and world, and the addition $(+1)$ infrastructural diplomacy. To conclude this section, the Indonesian MOFA perceives that ASEAN is important, and exerting influence in the regional organization has and will continue in the near and distant future. But the leadership of Indonesia in ASEAN is no longer a priority, in which Indonesia perceives that being active in ASEAN and continue to provide a limited contribution is imperative. Despite so, forms of leadership evident in past presidencies have been absent, simply because both Jokowi's grand foreign policy strategy and the specific foreign policies executed by the Indonesian MOFA do not list a leadership role in ASEAN as a priority.

\section{Conclusion}

Indonesia is a not a 'born leader of ASEAN' as indicated by Widyaningsih and Robert in 2015. Despite having the capacity to lead the regional organization in many fronts, including the formation of new institutions and the introduction of new norms, the process of leadership goes through a constructed process, based on both systemic and domestic determinants. This article contributes to the discourse of neoclassical realism in the study of state to international organizational interactions, and contemporary studies on Jokowi's leadership role in ASEAN. As the article argues, the reason for Indonesia's decline of the leadership role in ASEAN during Jokowi's first term of the presidency is because of Indonesia's relative power in the International system which happens to face a rising assertive China in Southeast Asia, leading to the implementation of a foreign policy grand strategy that goes against past regionalism-based policies. Furthermore, the decline can be attributed to the shared perception of the irrelevance of ASEAN leadership in Jokowi's presidency between the foreign 
policy executives defined in this article, which include the President of Indonesia and the Indonesian Foreign Affairs Ministry. Therefore, the decline of Indonesia's leadership role is concluded due to the systemic stimuli and domestic constraints.

\section{Limitations and Study Forward}

A major limitation to the study concerns the intervening variable of the domestic constraints. As systemic stimuli can be relatively simple to explain with the assertive rise of China, the exclusion of other possible intervening variables such as strategic culture, state-society relations, and domestic institutions, may become of great significance in future studies as alternative domestic constraints. Furthermore, future studies will need to explore more empirical study cases to prove how foreign policy behaviors are shaped in cases of state to International organization relations.

\section{References}

Acharya, A. (2018). Doomed by Dialogue: Will ASEAN Survive Great Power Rivalry in Asia? In International Relations and Asia's Southern Tier (pp. 77-91). https://doi.org/10.1007/978-981-10-3171-7_6

Aji, N., \& Dartanto, T. (2018). Behind the Jokowi's victory: did economic voting matter in the 2014 Indonesian presidential election? Asia-Pacific Journal of Regional Science, 2(1), 115-138. https://doi.org/10.1007/s41685o18-0083-3

Andika, M. T. (2016). An Analysis of Indonesia Foreign Policy Under Jokowi's Pro-People Diplomacy. An Analysis of Indonesia Foreign Policy Under Jokowi's Pro-People Diplomacy, 1(2), 93-105. https://doi.org/10.14710/ip.vii2.14284

Anugrah, A. P., Putra, B. A., \& Burhanuddin. (2020). Implementation of coral triangle initiative on coral reefs, fisheries, and food security (CTI-CFF) in Indonesia and Philippines Implementation of coral triangle initiative on coral reefs, fisheries, and food security (CTI-CFF) in Indonesia and Philippines. IOP Conference Series: Earth and Environmental Science , 1-6. https://doi.org/10.1088/1755-1315/575/1/o12154

Anwar, D. F. (2020). Indonesia and the ASEAN outlook on the Indo-Pacific. International Affairs, 96(1), 111-129. https://doi.org/10.1093/IA/IIZ223

Bagus, G., Agastia, D., \& Perwita, A. A. B. (2015). Jokowi's Maritime Axis: Change and Continuity of Indonesia's Role in Indo-Pacific. Journal of ASEAN Studies, 3(1), 32-41. Retrieved from http://www.dndph.org/2015updates/philippines-

Beach, D. (2019). Analyzing Foreign Policy - Derek Beach|Rasmus Brun Pedersen - Macmillan International Higher Education. Retrieved from https://www.macmillanihe.com/page/detail/Analyzing-Foreign-Policy/?K=978135 2008067

Caballero-Anthony, M. (2005). Regional Security in Southeast Asia: Beyond the ASEAN Way. Retrieved from https://books.google.com.au/books?id=gsZ6BwAAQBAJ\&printsec=frontcover\#v=onepage\&q\&f=false

Connelly, A. L. (2015). Sovereignty and the Sea: President Joko Widodo's Foreign Policy Challenges. Contemporary Southeast Asia: A Journal of International and Strategic Affairs, 37(1), 1-28. https://doi.org/10.1355/cs37-1a

Darwis, Putra, B. A., Benny, G., Baharuddin, A., \& Burhanuddin. (2020). The Asean Economic Community and Determinant Factors in the Expansion of Indonesian Businessmen in the Southeast Asian Market. Academy of Entrepreneurship Journal, 26(4). Retrieved from https://www.abacademies.org/articles/the-aseaneconomic-community-and-determinant-factors-in-the-expansion-of-indonesian-businessmen-in-thesoutheast-asian-market-9892.html

Darwis, Putra, B. A., \& Cangara, A. R. (2020). Navigating Through Domestic Impediments: Suharto and Indonesia's Leadership in ASEAN. International Journal of Innovation, Creativity and Change, 13(6), 808-824. Retrieved from https://www.ijicc.net/index.php/volume-13-2020/189-vol-13-iss-6

Emmers, R. (2014). Indonesia's role in ASEAN: A case of incomplete and sectorial leadership. Pacific Review, 27(4), 543-562. https://doi.org/10.108o/o9512748.2014.924230

Haryono, E. (2019). Economic Diplomacy as Indonesian Foreign Policy Orientation in 2015-2018: Challenges and Opportunities. Jurnal Global E Strategis, 13(2), 46. https://doi.org/10.20473/jgs.13.2.2019.46-61

Heydarian, R. J. (2017). Tragedy of Small Power Politics: Duterte and the Shifting Sands of Philippine Foreign Policy. Asian Security, 13(3), 220-236. https://doi.org/10.1080/14799855.2017.1354569

Inayati, R. S. (2016). Pemerintahan Susilo Bambang Yudhoyono dan Politik Luar Negeri Indonesia. Jurnal Penelitian Politik, 2(1), 35-49. https://doi.org/10.14203/JPP.V2I1.390 
Kaarbo, J. (2015). A Foreign Policy Analysis Perspective on the Domestic Politics Turn in IR Theory. International Studies Review, 17(2), 189-216. https://doi.org/10.1111/misr.12213

Kitchen, N. (2010). Systemic pressures and domestic ideas: A neoclassical realist model of grand strategy formation. Review of International Studies, 36(1), 117-143. https://doi.org/10.1017/So260210509990532

Kozub-Karkut, M. (2019). Neoclassical Realism and Foreign Policy Analysis - A Possible Way of Integration? Teoria Polityki, 3, 201-227. https://doi.org/10.4467/25440845tp.19.011.10294

Kuncoro, J., Direktur, H., Staf, S., Pimpinan, D., Luar, K., Pusdiklat, N., \& Republik Indonesia, K. (2020). Diplomasi Maritim: Meletakkan Fondasi Poros Maritim Dunia. In |Jurnal Maritim Indonesia|Juni (Vol. 2020). https://doi.org/10.25008/IJM.V8I1.55

Legro, J. W., \& Moravcsik, A. (1999). Is Anybody Still a Realist? International Security, 24(2), 5-55. https://doi.org/10.1007/BFo2903199

Ministry of Foreign Affairs Indonesia. (n.d.). Performance Report 2016: Ministry of Foreign Affairs Indonesia. Jakarta.

Ministry of Foreign Affairs Indonesia. (2019). Performance Report 2019: Ministry of Foreign Affairs Indonesia. Jakatya.

Negara, S. D., \& Suryadinata, L. (2019). China's Maritime Silk Road Initiative and Indonesia. In China's Maritime Silk Road Initiative and Southeast Asia (pp. 65-94). https://doi.org/10.1007/978-981-32-9275-8_3

Parameswaran, P. (2014). Is Indonesia Turning Away From ASEAN Under Jokowi? - The Diplomat. Retrieved June 20, 2020, from The Diplomat website: https://thediplomat.com/2014/12/is-indonesia-turning-away-fromasean-under-jokowi/

Pham, Q. M. (2010). The South China Sea security problem: Towards regional cooperation. Asia Europe Journal, 8(3), 427-434. https://doi.org/10.1007/s10308-010-0283-6

Pisanò, A. (2014). Human Rights and Sovereignty in the ASEAN Path Towards a Human Rights Declaration. Human Rights Review, 15(4), 391-411. https://doi.org/10.1007/s12142-014-0313-7

Poole, A. (2015). The Foreign Policy Nexus: National Interests, Political Values and Identity. In Indonesia's Ascent (pp. 155-176). https://doi.org/10.1057/9781137397416_8

Putra, B A. (2020). Extending the discourse of environmental securitization: Indonesia's securitization of illegal, unreported, and unregulated fishing and China's belligerence at sea. IOP Conf. Ser.: Earth Environ. Sci, 575, 12242. https://doi.org/10.1088/1755-1315/575/1/o12242

Putra, Bama Andika. (2015). Indonesia's leadership role in ASEAN: History and future prospects. International EJournal of Advances in Social Science, 1(2), 188-197. https://doi.org/10.5281/ZENODO.3895412

Putra, Bama Andika. (2017). The Surfacing of Great Power Rivalries in The Indian Ocean: Indonesia's Urgency to Empower The Indian Ocean Rim Association. In Journal of Society and Governance (Vol. 1).

Putra, Bama Andika. (2020). Human Rights Concerns in Indonesia's Counterterrorism Policies: The Emergence of a Domestic Security Dilemma in Indonesia's Densus 88 Security Posture. Academic Journal of Interdisciplinary Studies, 9(6), 206. https://doi.org/10.36941/ajis-2020-0125

Putra, Bama Andika. (2021). Comprehending Brunei Darussalam's vanishing claims in the South China Sea: China's exertion of economic power and the influence of elite perception. Cogent Social Sciences, 7(1), 1858563. https://doi.org/10.108o/23311886.2020.1858563

Rathbun, B. (2008). A rose by any other name: Neoclassical realism as the logical and necessary extension of structural realism. Security Studies, 17(2), 294-321. https://doi.org/10.108o/o9636410802098917

Rattanasevee, P. (2014). Leadership in ASEAN: The Role of Indonesia Reconsidered. Asian Journal of Political Science, 22(2), 113-127. https://doi.org/10.1080/02185377.2014.895912

Rijal, N. K. (2019). Smart Maritime Diplomacy: Diplomasi Maritim Indonesia Menuju Poros Maritim Dunia. Jurnal Global \& Strategis, 13(1), 63. https://doi.org/10.20473/jgs.13.1.2019.63-78

Rioux, B., Galkin, P., \& Wu, K. (2019). An economic analysis of China's domestic crude oil supply policies. Chinese Journal of Population Resources and Environment, 17(3), 217-228. https://doi.org/10.1080/10042857.2019.1650247

Ripsman, N. M., Taliaferro, J. W., \& Lobell, S. E. (2016). Neoclassical realist theory of international politics. New York: Oxford University Press.

Rizka, B., Lismalinda, Adnan, Moriyanti, \& Faisal. (2020). Jokowi vs Prabowo: The politeness and its violation in political communication of Indonesian president candidates. Humanities and Social Sciences Reviews, 8(3), 31-38. https://doi.org/10.18510/hssr.2020.834

Roberts, C. B., \& Widyaningsih, E. (2015). Indonesian Leadership in ASEAN: Mediation, Agency and ExtraRegional Diplomacy. Indonesia's Ascent, 264-286. https://doi.org/10.1057/9781137397416_13

Rose, G. (1998). Review: Neoclassical Realism and Theories of Foreign Policy. World Politics, 519, 144-172.

Schweller, R. L. (2004). Unanswered Threats: A Neoclassical Realist Theory of Underbalancing. International Security, 29(2), 159-201. https://doi.org/10.2307/4137589 
Simon, S. W. (2012). Conflict and Diplomacy in the South China Sea. Asian Survey, 52(6), 995-1018. https://doi.org/10.1525/as.2012.52.6.995

Storey, I. (2018). ASEAN's Failing Grade in the South China Sea. In International Relations and Asia's Southern Tier (pp. 111-124). https://doi.org/10.1007/978-981-10-3171-7_8

Syailendra, E. A. (2017). A nonbalancing act: Explaining Indonesia's failure to balance against the Chinese threat. Asian Security, 13(3), 237-255. https://doi.org/10.1080/14799855.2017.1365489

Taliaferro, J. W. (2004). Balancing Risks: Great Power Intervention in the Periphery. https://doi.org/10.7591/J.CTVV414NR

Tan, S. S. (2015). Indonesia among the Powers: Will ASEAN Still Matter to Indonesia? In Indonesia's Ascent (pp. 287-307). https://doi.org/10.1057/9781137397416_14

Tokan, B. (2019). Chinese investment in Indonesia reaches US\$2.3 billion - ANTARA News. Retrieved June 20, 2020, from Antara News website: https://en.antaranews.com/news/136671/chinese-investment-in-indonesiareaches-us23-billion

Warburton, E. (2016). Jokowi and the New Developmentalism. Bulletin of Indonesian Economic Studies, 52(3), 297320. https://doi.org/10.1080/ooo74918.2016.1249262

Widiyanta, D. (2016). Peran Indonesia dalam mewujudkan demokratisasi ASEAN 1998 - 2010. MOZAIK: Jurnal Ilmu-Ilmu Sosial Dan Humaniora, 8(1). https://doi.org/10.21831/moz.v8i1.10767

York, M. (2015). ASEAN'S ambiguous role in resolving South China Sea disputes. In Jurnal Hukum Internasional (Vol. 12). Retrieved from www.dfa.gov.ph/index.php/2013-06-27-21-50-36/dfa-releases/3856-secretary-del-

Zakaria, F. (1991). Realism and Domestic Politics: A Review Essay. International Security, 177-198.

Zakaria, F. (1998). Realism and America's Rise: A Review EssayFrom Wealth to Power: The Unusual Origins of America's World Role. International Security, 23(2), 182. https://doi.org/10.2307/2539382 